\title{
The effects of simvastatin on the C-reactive protein level and lipid profile in the acute phase of ischaemic stroke in relation to $-717 \mathrm{~A}>\mathrm{G}$ CRP gene polymorphism
}

\section{Wpływ simwastatyny na stężenie białka C-reaktywnego i profil lipidowy u chorych w ostrej fazie niedokrwiennego udaru mózgu w zależności od polimorfizmu -717A>G genu CRP}

\author{
Dariusz Kotlęga ${ }^{1,2} \bowtie$, Monika Białecka³, Mateusz Kurzawski³ ${ }^{3}$ Marek Droździk³ ${ }^{3}$ Monika Gołąb-Janowska, \\ Sylwester Ciećwież ${ }^{4}$, Przemysław Nowacki ${ }^{1}$
}

${ }^{1}$ Pomorski Uniwersytet Medyczny w Szczecinie, Katedra i Klinika Neurologii, ul. Unii Lubelskiej 1, 71-252 Szczecin

${ }^{2}$ Głogowski Szpital Powiatowy, Oddział Neurologii, ul. Kościuszki 15, 67-200 Głogów

${ }^{3}$ Pomorski Uniwersytet Medyczny w Szczecinie, Zakład Farmakologii Doświadczalnej i Klinicznej, al. Powstańców Wlkp. 72 , 70-111 Szczecin

${ }^{4}$ Pomorski Uniwersytet Medyczny w Szczecinie, Klinika Ginekologii i Uroginekologii, ul. Siedlecka 2, 72-010 Police

$\triangle$ dkotlega@poczta.onet.pl

\begin{abstract}
Introduction: The pathogenesis and risk of ischaemic stroke are associated with the inflammatory process that is involved in the development of atherosclerosis. The blood level of C-reactive protein (CRP) is a widely used predictor of inflammation. The level of this protein is used for the assessment of risk and prognosis in cardiovascular disorders and stroke. C-reactive protein level depends on genetic and environmental factors such as genetic polymorphism and statin use.

The aim of the study was to assess the potential effects of simvastatin on the CRP level and lipid profile in stroke in regard to the variant of $-717 \mathrm{~A}>\mathrm{G} C R P$ gene polymorphism.

Materials and methods: There were 125 subjects enrolled in the study, hospitalized with a diagnosis of ischaemic stroke (95 patients in group 1 and 30 patients in group 2). Patients in
\end{abstract}

group 1 were treated with a $40 \mathrm{mg}$ dose of simvastatin from the $1^{\text {st }}$ day; in group 2 simvastatin was not used. Blood CRP level and lipid profile were measured in all patients on day 1 and 10 after admission. The $-717 \mathrm{~A}>\mathrm{G} C R P$ gene polymorphism status was genotyped in all patients.

Results: In both groups there was a significant increase in CRP level, despite simvastatin treatment. No association was found between genotype and levels of both CRP and lipids change from the $1^{\text {st }}$ to the $10^{\text {th }}$ day.

Conclusions: Simvastatin does not affect the CRP level in relation to any of the $-717 \mathrm{~A}>\mathrm{G} C R P$ gene polymorphism variants in the acute phase of stroke. Simvastatin significantly changes lipid levels, but it does not depend on $-717 \mathrm{~A}>\mathrm{G} C R P$ gene polymorphism. Keywords: stroke; genetic polymorphism; C-reactive protein; lipids; atherosclerosis; statins.

\begin{abstract}
ABSTRAKT
Wstęp: Patogeneza i ryzyko wystąpienia udaru niedokrwiennego mózgu związane są z obecnością zmian zapalnych biorących udział w rozwoju miażdżycy. Powszechnie stosowanym wykładnikiem procesu zapalnego jest stężenie białka C-reaktywnego (CRP) w surowicy. Poziom CRP wykorzystuje się w ocenie ryzyka wystąpienia i rokowania w chorobach sercowo-naczyniowych oraz w udarze. Stężenie CRP podlega wpływom czynników genetycznych, takich jak polimorfizm genetyczny, oraz środowiskowym, wśród których znajduje się stosowanie statyn.

Celem pracy było ustalenie potencjalnego wpływu simwastatyny na stężenie CRP i profil lipidowy w udarze $\mathrm{z}$ uwzględnieniem wariantu polimorfizmu $-717 \mathrm{~A}>\mathrm{G}$ genu $C R P$.

Materiały i metody: Do badania włączono 125 chorych hospitalizowanych z powodu udaru niedokrwiennego mózgu. Na podstawie kryteriów włączenia i wyłączenia do I grupy zakwalifikowano 95, a do grupy II - 30 chorych. Pacjenci z grupy I otrzymywali simwastatynę w dawce $40 \mathrm{mg}$ od 1. doby,
\end{abstract}

natomiast w grupie II nie stosowano tego leczenia. U wszystkich chorych oznaczono stężenie CRP i profil lipidowy w 1. i 10. dobie hospitalizacji oraz oznaczono wariant polimorfizmu -717A $>\mathrm{G}$ genu $C R P$.

Wyniki: W grupie I i II odnotowano istotny wzrost stężenia CRP, pomimo leczenia simwastatyną. U osób w grupie I i II nie stwierdzono istotnego wpływu poszczególnych wariantów polimorfizmu -717A>G genu CRP na zmianę stężenia CRP i profilu lipidowego pomiędzy 1. a 10. dobą hospitalizacji.

Wnioski: Simwastatyna nie wpływa na stężenie CRP w ostrej fazie udaru mózgu w zależności od jakiegokolwiek wariantu polimorfizmu $-717 \mathrm{~A}>\mathrm{G}$ genu $C R P$. Zastosowanie simwastatyny w ostrej fazie udaru niedokrwiennego mózgu wyraźnie wpływa na profil lipidowy, przy czym efekt nie jest zależny od wariantów polimorfizmu $-717 \mathrm{~A}>\mathrm{G}$ genu $C R P$.

Słowa kluczowe: udar mózgu; polimorfizm; białko C-reaktywne; lipidy; miażdżyca; statyny. 


\section{INTRODUCTION}

Ischaemic stroke is the leading cause of death and permanent disability, especially after 60 years of age [1]. The main cause of stroke is atherosclerosis, which develops as a result of arterial endothelium dysfunction caused by many factors, such as hypertension, diabetes, lipids deposition (especially low density lipoproteins - LDL), inflammation, free radicals, infections, increased blood homocysteine level, and tobacco smoking [2]. Inflammatory factors play a crucial role in the process of atherogenesis. The inflammatory process is reflected in the level of acute phase proteins, such as C-reactive protein (CRP). $\mathrm{C}$-reactive protein plays a role in mediating complement activation, adhesion molecules synthesis and regulation of blood rheologic properties. The level of this protein is associated with the process of forming atherosclerotic plaque in carotid arteries. It positively correlates with the risk of vascular episodes, including cardioembolic stroke connected with atrial fibrillation $[3,4,5,6,7]$. High CRP levels were observed 1 and 3 months after stroke [4, 8]. Measurement of CRP level may be helpful in the assessment of recurrent stroke risk $[9,10]$. $\mathrm{C}$-reactive protein is a marker of increased 1-year risk in ischaemic stroke. C-reactive protein at discharge is related to later outcomes, and could be of greater utility for risk stratification [11]. Levels of CRP increase with stroke severity and are associated with higher mortality at the beginning and 3 months after the stroke [12, 13].

Expression of CRP is conditioned by genetic background. The CRP gene is located on chromosome 1 (1q21 to 1q23) and is characterized by genetic variation. There have been $30 \mathrm{CRP}$ gene single nucleotide polymorphisms (SNP) described [14]. There is an association between particular alleles of the CRP gene and diverse expression of CRP $[3,15,16,17,18,19,20,21]$. Variants that change the risk of ischaemic stroke, acute coronary syndrome, recurrent stroke, cardioembolic stroke and development of atherosclerosis in intracranial arteries were identified $[4,13,15,22]$.

The results of the association between CRP level and $-717 \mathrm{~A}>\mathrm{G}$ $C R P$ gene polymorphism are inconclusive. Significant increments in CRP concentrations in individuals carrying the $-717 \mathrm{G}$ allele in the acute phase of stroke were found when compared with the baseline state [23]. Other authors did not observe any effect of the above-mentioned SNP on CRP level $[19,20$, $24,25]$. The association of this SNP with myocardial infarct and coronary heart disease (CHD) supports the belief that carriers of the $-717 \mathrm{~A}$ allele of the $C R P$ gene are genetically predisposed to CHD [26]. On the other hand, other authors demonstrated that $-717 \mathrm{~A}>\mathrm{G} C R P$ gene polymorphism is associated with a decreased risk of myocardial infarct and CHD [20, 27]. The $\mathrm{G}$ to $\mathrm{A}$ exchange at the site of $-717 \mathrm{~A}>\mathrm{G} C R P$ gene polymorphism resulted in an increased transcriptional activity of the CRP gene promoter [28].

C-reactive protein level also depends on environmental factors, such as statin use $[18,29]$. Statins inhibit 3-hydroxy-3-methyl-glutaryl-CoA reduction to mevalonian, which results in decreased cholesterol synthesis. Rosuvastatin and atorvastatin exert the strongest effect on LDL, decreasing its level by up to $63 \%$ [30]. Statins demonstrate an anti-inflammatory effect by decreasing the number of inflammatory cells and by stabilizing atherosclerotic plaque [31,32]. The multidirectional activity of statins refers to a pleiotropic effect and is connected with the influence on coagulation, the complement system, and change in the activity of inflammatory cells [33]. Statins are widely used in primary and secondary prevention of cardiovascular episodes, including stroke and CHD. The use of statins decreases the relative risk of stroke by $21-28 \%$, and mortality by $9 \%[31,34,35]$. Atorvastatin treatment decreases the risk of recurrent stroke by $16 \%[36,37]$.

Pathogenesis and risk of ischaemic stroke are associated with the presence of the inflammatory process that is involved in atherosclerosis and non-valvular atrial fibrillation development. Blood CRP level reflects inflammation and may be used as a prognostic factor in stroke. Changes in the CRP level depend on genetic and environmental factors.

The aim of the study was to analyse the relationship between CRP level, lipid profile and simvastatin in the acute phase of stroke, including the potential effect of a variant of $-717 \mathrm{~A}>\mathrm{G}$ CRP gene polymorphism.

\section{MATERIALS AND METHODS}

125 Caucasian patients that were hospitalized between January 2008 and June 2010 in the Neurology Department of Pomeranian Medical University in Szczecin (in Poland) were enrolled in the study. Subjects were divided into two groups depending on the following criteria.

The main inclusion criterion was the diagnosis of ischaemic stroke, confirmed by the results of examination and brain computed tomography. Patients were older than 18 years, stroke was both of embolic and thrombotic types. Two groups were formed based on the lipid profile on the $1^{\text {st }}$ day after stroke. Group 1 consisted of patients with LDL $\geq 130 \mathrm{mg} / \mathrm{dL}$ or total cholesterol $(\mathrm{CH}) \geq 200 \mathrm{mg} / \mathrm{dL}$. In group 2 patients had LDL $<130 \mathrm{mg} / \mathrm{dL}$ and $\mathrm{CH}<200 \mathrm{mg} / \mathrm{dL}$. The exclusion criteria were body temperature of more than $37.4^{\circ} \mathrm{C}$, clinical or biochemical symptoms of infection, chronic inflammatory disorders, and cancers. Patients taking statins or other lipid-lowering drugs in the preceding year were also excluded from the study.

All subjects from group 1 received simvastatin $40 \mathrm{mg}$ daily starting from the $1^{\text {st }}$ day after stroke onset. Patients from group 2 were not treated with simvastatin. In all subjects $-717 \mathrm{~A}>\mathrm{G}$ CRP gene polymorphism was detected. Besides standard laboratory tests, lipid profile and blood CRP level were measured on admission and on the $10^{\text {th }}$ day of hospitalization.

The NIHSS scale (National Institutes of Health Stroke Scale) [29] was used for the evaluation of neurological deficit (0-42 points). Patients were evaluated immediately upon admission and before discharge from the hospital.

Blood serum CRP was measured on the $1^{\text {st }}$ and $10^{\text {th }}$ days of hospitalisation, using the immunoturbimetric method, strengthened with latex particles with a bottom detectability 
line amounting to $1 \mathrm{mg} / \mathrm{L}$, using the standard manufacturer's protocol (Fast Digest Bsh1236I, Fermentas UAB, Lithuania).

Venous blood was collected into EDTA tubes for DNA isolation. Detection of $C R P$ gene promoter polymorphism $717 \mathrm{~A}>\mathrm{G}$ (rs 2794521) was made using the PCR-RFLP method with Bsh12361 enzyme [26, 37].

The normal distribution of continuous variables was evaluated by the Shapiro-Wilk test. For asymmetric distribution of CRP, logarithmic transformation was applied. The examined groups were compared with the use of the non-parametric Mann-Whitney U-test. For fraction analysis of discrete variables the $\chi^{2}$ test was used. The one-way ANOVA test with LSD as a post hoc test or the non-parametric Kruskal-Wallis test were applied to analyse the interaction of the examined factors. Statistical significance was adopted as $\mathrm{p}<0.05$ for all tests.

\section{RESULTS}

According to the presented criteria, group 1 consisted of 95 patients with LDL level of $158.3 \mathrm{mg} / \mathrm{dL}(100-255), \mathrm{CH}$ of $238.8 \mathrm{mg} / \mathrm{dL}(65-396)$. Group 2 consisted of 30 patients with mean LDL level 108.9 mg/dL (55-142) and CH of $180.4 \mathrm{mg} / \mathrm{dL}$ (121-205).

As presented in Table 1, systolic blood pressure and diastolic blood pressure values on admission were higher in group 1.

There were also differences between groups in previous hypertension treatment and history of CHD. Significantly, more patients had not been taking hypotensives (48\% in group 1 vs. $73 \%$, Pearson's $\chi^{2}$ test, $\left.p=0.017\right)$. Coronary heart disease was more common in group 1 ( $40 \%$ vs. $17 \%, p=0.017$ ). There were no differences between groups in relation to other tested parameters.

Lipid level changes presented in Table 2 were not dependent on any of the $-717 \mathrm{~A}>\mathrm{G} C R P$ gene variants.

In both groups there was a significant increase in serum CRP level between the $1^{\text {st }}$ and the $10^{\text {th }}$ day (group 1: $5.8 \mathrm{mg} / \mathrm{L}$, SD $8.4 \mathrm{mg} / \mathrm{L}, \mathrm{p}<0.004$; group 2: $5.6 \mathrm{mg} / \mathrm{L}, \mathrm{SD} 6.5 \mathrm{mg} / \mathrm{L}$, $\mathrm{p}=0.047$ ), but it was not dependent on the CRP genotype (Tables 3 and 4). The intensification of the increase did not differ significantly between groups.

The distribution of gene variants in the groups was as follows: AA - 51 (54\%), AG - 38 (40\%), GG - $6(6 \%)$, in group 2: $\mathrm{AA}-16$ (54\%), AG - 12 (40\%), GG - 2 (7\%).

There were no statistical differences in the distribution of alleles between groups.

\section{DISCUSSION}

Considering the effect of statins on inflammation modification (pleiotropic effect), the inclusion of atrial fibrillation patients is reasonable. It has been shown that inflammation plays a role in the pathogenesis of atrial fibrillation, and CRP level is an independent risk factor of atrial fibrillation incidence $[38,39,40]$.

TABLE 1. Comparison of selected parameters in groups 1 and 2

\begin{tabular}{|c|c|c|c|c|c|c|c|}
\hline \multirow{2}{*}{ Parameter } & \multicolumn{3}{|c|}{ Group 1} & \multicolumn{3}{|c|}{ Group 2} & \multirow{2}{*}{$\mathrm{p}$} \\
\hline & mean & SD & $\mathbf{n}$ & mean & SD & $\mathrm{n}$ & \\
\hline Age (years) & 64.7 & 10.3 & 95 & 63 & 13.8 & 30 & NS \\
\hline $\operatorname{BMI}\left(\mathrm{kg} / \mathrm{m}^{2}\right)$ & 27.6 & 4.4 & 64 & 27.8 & 3.6 & 22 & NS \\
\hline SBP on admission (mmHg) & 164.1 & 30.2 & 95 & 148.3 & 30.5 & 30 & 0.01 \\
\hline DBP on admission (mmHg) & 95 & 18.6 & 95 & 84 & 16.3 & 30 & 0.004 \\
\hline IMT L (mm) & 0.09 & 0.02 & 92 & 0.09 & 0.02 & 28 & NS \\
\hline IMT R (mm) & 0.08 & 0.02 & 92 & 0.08 & 0.02 & 28 & NS \\
\hline NIHSS on admission & 6.2 & 5 & 95 & 6.6 & 5.1 & 30 & NS \\
\hline NIHSS on discharge & 3.4 & 4.6 & 95 & 2.9 & 3.8 & 30 & NS \\
\hline
\end{tabular}

BMI - body mass index; SBP - systolic blood pressure; DBP - diastolic blood pressure; IMT L - left intima-media thickness; IMT R - right intima-media thickness; NIHSS - National Institutes of Health Stroke Scale

TABLE 2. Comparison of simvastatin effect on lipids between groups

\begin{tabular}{|c|c|c|c|c|c|c|}
\hline \multirow{2}{*}{ Parameter (mg/dL) } & \multicolumn{3}{|c|}{ Group 1} & \multicolumn{3}{|c|}{ Group 2} \\
\hline & mean & SD & $\mathrm{p}$ & mean & SD & $p$ \\
\hline $\mathrm{CH}$ & 238.8 & 40.9 & \multirow{2}{*}{$<0.001$} & 180.4 & 20.1 & \multirow{2}{*}{ NS } \\
\hline $\mathrm{CH}$ on $10^{\text {th }}$ day & 164.6 & 29.8 & & 178.5 & 28.9 & \\
\hline HDL & 50.5 & 12.3 & \multirow{2}{*}{$<0.001$} & 47.3 & 11.8 & \multirow{2}{*}{$<0.001$} \\
\hline HDL on $10^{\text {th }}$ day & 40.0 & 9.7 & & 41 & 9.9 & \\
\hline LDL on $10^{\text {th }}$ day & 97.8 & 25.4 & $<0.001$ & 109.8 & 23.9 & NS \\
\hline TG & 167.3 & 101.1 & \multirow{2}{*}{0.01} & 111.7 & 43.8 & \multirow{2}{*}{0.017} \\
\hline TG on $10^{\text {th }}$ day & 144.9 & 67.4 & & 155.4 & 96.3 & \\
\hline
\end{tabular}

CH - total cholesterol; HDL - high density lipoproteins; LDL - low density lipoproteins; TG - triglycerides 
TABLE 3. Comparison of C-reactive protein level change in group 1 in relation to $-717 \mathrm{~A}>\mathrm{G} C R P$ genotype

\begin{tabular}{lcccc} 
Genotype & $\mathbf{n}$ & Mean $(\mathbf{m g} / \mathbf{d L})$ & SD & p (ANOVA test) \\
\cline { 1 - 4 } AA & 51 & 6 & 13.7 & \\
\cline { 1 - 4 } AG & 38 & 1.7 & 13.7 & NS \\
\cline { 1 - 4 } GG & 6 & 3.9 & 15.4
\end{tabular}

TABLE 4. Comparison of C-reactive protein level change in group 2 in relation to $-717 \mathrm{~A}>\mathrm{G} C R P$ genotype

\begin{tabular}{lrrrrl} 
Genotype & $\mathbf{n}$ & Mean $(\mathrm{mg} / \mathrm{dL})$ & $\mathrm{SD}$ & $\mathbf{p}$ (ANOVA test) \\
\cline { 1 - 4 } AA & 16 & 2.7 & 9.7 & NS \\
\cline { 1 - 4 } AG & 12 & 16.6 & 32.6 & \\
\cline { 1 - 4 } GG & 2 & 5.7 & 1.7 & \\
\hline
\end{tabular}

There were differences found between subjects assigned to groups 1 and 2. The differences in lipid profile resulted from the study design. In group 1 CHD was more frequent and there were higher values of blood pressure measured on admission. Patients in group 2 had been using hypotensives more often. Such differences may be connected with the fact that dyslipidaemia is associated with higher risk of hypertension and CHD, and this may also be connected with the study design.

C-reactive protein level between the $1^{\text {st }}$ and the $10^{\text {th }}$ day was higher in both groups. The increase in CRP despite simvastatin use may be due to stroke evolution and activation of the inflammatory process [41]. It was shown that the CRP level changes or remains at a stable, but higher level after stroke [8]. Such an effect was not noticed in our study, but the patients were only followed up for 10 days. The question emerges of when the pleiotropic effect of statins can be observed after stroke. The first effect of statin use is evident after 2 days in reduced CRP level, but this observation was made in strokefree patients [42]. A longer time may be necessary to observe a more pronounced effect.

The effect of simvastatin on lipid profile was evident and diverse in the study groups. This is consistent with other studies that showed hypolipemic effect after 14 days [43].

In both groups there was high density lipoproteins (HDL) decrease, which plays a protective role. According to other studies, simvastatin should exert no effect or elevate the HDL level [44]. Our observation may result from the short period of the study. On the other hand, the strong effect on other lipids may be proof of the different metabolism and effect of simvastatin on HDL. Decreased level of LDL may be connected with inflammation activation in the acute phase of ischaemic stroke. Such inflammatory factors may be more strongly associated with HDL compared to other lipids metabolism. This presumption is supported by the fact that HDL is involved in the transport of antioxidative enzymes, such as paraoxonase and platelet-activating factor acetylhydrolase [45].

The results of our study suggest that rapid statin introduction in stroke patients may have beneficial effects due to the pleiotropic effect initiation as the evident effect on the lipid profile was observed.
Another aim of our study was to analyse the effect of simvastatin on the CRP level in relation to $-717 \mathrm{~A}>\mathrm{G} C R P$ gene polymorphism as more results appear [46]. We did not reveal such an effect, so none of the genotypes can be used as prognostic factors in the acute phase of stroke. There was also no effect of simvastatin use on the lipid profile in relation to any of the genotypes. Such a relationships has not been investigated in other studies so far.

As we examined patients in the acute phase of stroke, this could have had an influence on the results. The potential pleiotropic effect of simvastatin reflected in CRP change could be dimmed by the active inflammatory process. We also cannot exclude that clinically silent infection biased our results, although we included only patients without symptoms of infection. On the other hand, it was interesting for us to elucidate this acute-phase period, as interactions between statins, polymorphism and CRP are still not fully known.

\section{CONCLUSIONS}

In the current study we found that simvastatin use in the acute phase of stroke does not prevent CRP increase. Simvastatin effect on CRP in the acute phase of stroke is not associated with $-717 \mathrm{~A}>\mathrm{G}$ CRP gene polymorphism. Simvastatin use in the acute phase of stroke significantly changes lipid profile, but it does not depend on $-717 \mathrm{~A}>\mathrm{G} C R P$ gene polymorphism.

\section{REFERENCES}

1. Warlow C, Sudlow C, Dennis M, Wardlaw J, Sandercock P. Stroke. Lancet 2003;362:1211-24. doi: 10.1016/S0140-6736(03)14544-8.

2. Stoll G, Bendszus M. Inflammation and atherosclerosis: novel insights into plaque formation and destabilization. Stroke 2006;37(7):1923-32. doi: 10.1161/01.STR.0000226901.34927.10.

3. Andersson J, Johansson L., Ladenvall P, Wiklund PG, Stegmayr B, Jern C, et al. C-reactive protein is a determinant of first-ever stroke: prospective nested case-referent study. Cerebrovasc Dis. 2009;27(6):544-51. doi: 10.1159/000214217.

4. Ladenvall C, Jood K, Blomstrand C, Nilsson S, Jern C, Ladenvall P. Serum C-reactive protein concentration and genotype in relation to ischemic stroke subtype. Stroke 2006;37(8):2018-23. doi: 10.1161/01. STR.0000231872.86071.68.

5. Lip GY, Patel JV, Hughes E, Hart RG. High-sensitivity C-reactive protein and soluble CD40 ligand as indices of inflammation and platelet activation in 880 patients with nonvalvular atrial fibrillation: relationship to stroke risk factors, stroke risk stratification schema and prognosis. Stroke 2007;38(4):1229-37. doi: 10.1161/01.STR.0000260090.90508.3e.

6. Ridker PM, Cuchman M, Stampfer MJ, Tracy RP, Hennekens CH. Inflammation, aspirin and the risk of cardiovascular disease in apparently healthy men. N Engl J Med 1997;336(14):973-9. doi: 10.1056/ NEJM199704033361401.

7. Schlager O, Exner M, Mlekusch W, Sabeti S, Amighi J, Dick P, et al. C-reactive protein predicts future cardiovascular events in patients with carotid stenosis. Stroke 2007;38(4):1263-8. doi: 10.1161/01.STR.0000259890.18354. $\mathrm{d} 2$.

8. Elkind MS, Coates K, Tai W, Paik MC, Boden-Albala B, Sacco RL. Levels of acute phase proteins remain stable after ischemic stroke. BMC Neurol 2006;6:37. doi: 10.1186/1471-2377-6-37.

9. Shantikumar S, Grant PJ, Catto AJ, Bamford JM, Carter AM. Elevated C-reactive protein and long-term mortality after ischaemic stroke: 
relationship with markers of endothelial cell and platelet activation. Stroke 2009;40(3):977-9. doi: 10.1161/STROKEAHA.108.525105.

10. Welsh P, Lowe GD, Chalmers J, Campbell DJ, Rumley A, Neal BC, et al. Associations of proinflammatory cy tokines with the risk of recurrent stroke. Stroke 2008;39(8);2226-30. doi: 10.1161/STROKEAHA.107.504498.

11. Di Napoli M, Papa F, Bocola V. C-reactive protein in ischemic stroke: an independent prognostic factor. Stroke 2001;32(4):917-24.

12. Elkind MS, Tai W, Coates K, Paik MC, Sacco RL. High-sensitivity C-reactive protein, lipoprotein-associated phospholipase A2, and outcome after ischaemic stroke. Arch Intern Med 2006;166(19):2073-80. doi: 10.1001/ archinte.166.19.2073.

13. Montaner J, Fernandez-Cadenas I, Molina CA, Ribó M, Huertas R, Rosell A et al. Poststroke C-reactive protein is a powerful prognostic tool among candidates for thrombolysis. Stroke 2006;37(5):1205-10.

14. Morita A, Nakayama T, Soma M. Association study between C-reactive protein genes and ischemic stroke in Japanese subjects. Am J Hypertens 2006;19(6):593-600. doi: 10.1016/j.amjhyper.2005.11.015.

15. Assayag EB, Shenhar-Tsafaty S, Bova I, Berliner S, Usher S, Peretz H, et al. Association of the $-757 \mathrm{~T}>\mathrm{C}$ polymorphism in the CRP gene with circulating C-reactive protein levels and carotid atherosclerosis. Thromb Res 2009;124(4):458-62. doi: 10.1016/j.thromres.2009.04.008.

16. Brull DJ, Serrano N, Zito F, Jones L, Montgomery HE, Rumley A, et al. Human CRP gene polymorphism influences CRP levels: implications for the prediction and pathogenesis of coronary heart disease. Arterioscler Thromb Vasc Biol 2003;23(11):2063-9. doi: 10.1161/01.ATV.0000084640.21712.9C.

17. Elliott P, Chambers JC, Zhang W, Clarke R, Hopewell JC, Peden JF, et al. Genetic loci influencing C-reactive protein levels and risk of coronary heart disease. JAMA 2009;302(1):37-48. doi: 10.1001/jama.2009.954.

18. Kathiresan S, Larson MG, Vasan RS, Guo CY, Gona P, Keaney JF, et al. Contribution of clinical correlates and $13 \mathrm{C}$-reactive protein gene polymorphisms to interindividual variability in serum C-reactive protein level. Circulation 2006;113(11):1415-23. doi: 10.1161/CIRCULATIONAHA.105.591271.

19. Kovacs A, Green F, Hansson LO, Lundman P, Samnegard A, Boquist S, et al. A novel common single nucleotide polymorphism in the promoter region of the C-reactive protein gene associated with the plasma concentration of C-reactive protein. Atherosclerosis 2005;178(1):193-8. doi: 10.1016/j. atherosclerosis.2004.08.018.

20. Miller DT, Zee RY, Danik JS, Kozlowski P, Chasman DI, Lazarus R, et al. Association of common CRP gene variants with CRP levels and cardiovascular events. Ann Hum Genet 2005;69:623-38. doi: 10.1111/j.15298817.2005.00210.x

21. Pai JK, Mukamal KJ, Rexrode KM, Rimm EB. C-reactive protein (CRP) gene polymorphisms, CRP levels, and risk of incident coronary heart disease in two nested case-control studies. PLoS ONE 2008;3(1):e1395. doi: 10.1371/journal.pone.0001395.

22. Arenillas JF, Massot A, Alvarez-Sabin J, Fernandez-Cadenas I, del RioEspinola A, Chacon P, et al. C-reactive protein gene C1444T polymorphism and risk of recurrent ischemic events in patients with symptomatic intracranial atherostenoses. Cerebrovasc Dis 2009;28(1):95-102. doi: 10.1159/000222660.

23. Assayag EB, Shenhar-Tsarfaty S, Bova I, Berliner S, Shopin L, Peretz H, et al. Triggered $\mathrm{C}$-reactive protein (CRP) concentrations and the CRP gene $717 \mathrm{~A}>\mathrm{G}$ polymorphism in acute stroke or transient ischaemic attack. Eur J Neurol 2007;14(3):315-20. doi: 10.1111/j.1468-1331.2006.01661.x.

24. Pai JK, Kim OY, Koh SJ, Jang Y, Chae JS, Kim JY, et al. Additive effect of interleukin- 6 and C-reactive protein (CRP) single nucleotide polymorphism on serum CRP concentration and other cardiovascular risk factors. Clin Chim Acta 2007;380(1-2):68-74. doi: 10.1016/j.cca.2006.11.011.

25. Toss H, Lindahl B, Siegbahn A, Wallentin L. Prognostic influence of increased fibrinogen and C-reactive protein levels in unstable coronary artery disease. Circulation 1997;96:4204-10.

26. Chen J, Zhao J, Huang J, Su S, Qiang B, Gu D. -717A > G polymorhism of human C-reactive gene associated with coronary heart disease in ethnic Han Chinese: the Beijing atherosclerosis study. J Mol Med 2005(1);83:72-8. doi: 10.1007/s00109-004-0585-5.
27. Wang Q, Ding H, Tang JR, Zhang L, Xu YJ, Yan JT, et al. C-reactive protein polymorphisms and genetic susceptibility to ischemic stroke and hemorrhagic stroke in the Chinese Han population. Acta Pharmacol Sin 2009;30(3):291-8. doi: 10.1038/aps.2009.14.

28. Wang L, Lu X, Li Y, Chen S, Gu D. Functional analysis of thee C-reactive protein (CRP) gene $-717 \mathrm{~A}>\mathrm{G}$ polymorphism associated with coronary heart disease. BMC Med Genet 2009;10:73.

29. Pearson TA, Mensah GA, Alexander RW, Anderson JL, Cannon RO $3^{\text {rd }}$, Criqui $\mathrm{M}$, et al. Markers of inflammation and cardiovascular disease: application to clinical and public health practice: A statement for healthcare professionals from the Centers for Disease Control and Prevention and the American Heart Association. Circulation 2003;107(3):499-511.

30. Toth PP, Davidson MH. High-dose statin therapy: benefits and safety in aggressive lipid lowering. J Fam Pract 2008;57:S29-36.

31. Kotlęga D, Ciećwież S, Turowska-Kowalska J, Nowacki P. Pathogenetic justification of statin use in ischaemic stroke prevention according to inflammatory theory in development of atherosclerosis. Neurol Neurochir Pol 2012;46(2):176-83.

32. Stüve O, Youssef S, Steinman L, Zamvil SS. Statins as potential therapeutic agents in neuroinflammatory disorders. Curr Opin Neurol 2003;16(3):393401. doi: 10.1097/01.wco.0000073942.19076.d1.

33. Liao JK. Clinical implications for statin pleiotropy. Curr Opin Lipidol 2005;16(6):624-9.

34. Amarenco P, Labreuche J, Lavallee P, Touboul PJ. Statins in stroke prevention and carotid atherosclerosis: systematic review and upto-date meta-analysis. Stroke 2004;35(12):2902-9. doi: 10.1161/01. STR.0000147965.52712.fa.

35. Collins R, Armitage J, Parish S, Sleight P, Peto R. Effects of cholesterollowering with simvastatin on stroke and other major vascular events in 20536 people with cerebrovascular disease or other high-risk conditions. Lancet 2004;363:757-67. doi: 10.1016/S0140-6736(04) 15690-0.

36. Amarenco P, Bogousslavsky J, Callahan A. $3^{\text {rd }}$, Goldstein LB, Hennerici M, Rudolph AE, et al. High-dose atorvastatin after stroke or transient ischaemic attack. N Engl J Med 2006;355(6):549-59. doi: 10.1056/NEJMoa061894.

37. Kotlęga D, Nowacki P, Białecka M, Kurzawski M, Droździk M, Ciećwież S. Association between CRP gene polymorphism 717A/G, C-reactive protein and neurological deficit in ischaemic stroke. J Clin Neurosci 2014;21:574-7. doi: http://dx.doi.org/10.1016/j.jocn.2013.06.016.

38. Anderson JL, Maycock CA, Lappe DL, Crandall BG, Horne BD, Bair TL, et al. Frequency of elevation of $\mathrm{C}$-reactive protein in atrial fibrillation. Am J Cardiol 2004;94(10):1255-9. doi: 10.1016/j.amjcard.2004.07.108.

39. Hadi HA, Mahmeed WA, Suwaidi JA, Ellahham S. Pleiotropic effects of statins in atrial fibrillation patients: the evidence. Vasc Health Risk Manag 2009;5(3): 533-51.

40. Sata N, Hamada N, Horinouchi T, Amitani S, Yamashita T., Moriyama Y. C-reactive protein and atrial fibrillation. Jpn Heart J 2004;45(3):441-5.

41. Maas MB, Furie KL. Molecular biomarkers in stroke diagnosis and prognosis. Biomark Med 2009;3(4):363-83. doi: 10.2217/bmm.09.30.

42. Li JJ, Wang Y, Nie SP, Zhang CY, Li YS, Hui RT, et al. Reduction of C-reactive protein by a single $80 \mathrm{mg}$ of simvastatin in patients with unstable angina. Clin Chim Acta 2007;376:163-7. doi: 10.1016/j.cca.2006.08.012.

43. Smilde TJ, van Wissen S, Wollersheim H, Trip MD, Kastelein JJ, Stalenhoef AF. Effect of aggressive versus conventional lipid lowering on atherosclerosis progression in familial hypercholesterolaemia (ASAP): a prospective, randomised, double-blind trial. Lancet 2001;357:577-81.

44. Li JJ, Chen MZ, Chen X, Fang CH. Rapid effects of simvastatin on lipid profile and C-reactive protein in patients with hypercholesterolemia. Clin Cardiol 2003;26(10):472-6.

45. Libby P, Ridker PM, Maseri A. Inflammation and atherosclerosis. Circulation 2002;105(9):1135-43.

46. Akbarzadeh NR, Ghaderian SM, Tabatabaei Panah AS. C-reactive protein (CRP) gene polymorphisms: implication in CRP plasma levels and susceptibility to acute myocardial infarction. Mol Biol Rep 2012;39(4): 3705-12. doi: 10.1007/s11033-011-1145-z. 